\section{Kidney \\ Blood Pressure Research}

Original Paper
Kidney Blood Press Res 2015;40:366-373

\begin{tabular}{l|l}
\hline DOI: $10.1159 / 000368512$ & C 2015 S. Karger AG, Basel
\end{tabular}

www.karger.com/kbr

1423-0143/15/0404-0366\$39.50/0

Accepted: April 30, 2015

This is an Open Access article licensed under the terms of the Creative Commons AttributionNonCommercial 3.0 Unported license (CC BY-NC) (www.karger.com/OA-license), applicable to the online version of the article only. Distribution permitted for non-commercial purposes only.

\title{
Iron Status and Inflammation in Early Stages of Chronic Kidney Disease
}

\author{
Ewelina Łukaszyk ${ }^{\mathrm{a}}$ Mateusz Łukaszyk ${ }^{\mathrm{b}}$ Ewa Koc-Żórawskac Jolanta Tobolczyk ${ }^{\mathrm{b}}$ \\ Anna Bodzenta-Łukaszyk ${ }^{\mathrm{b}}$ Jolanta Małyszko ${ }^{a}$

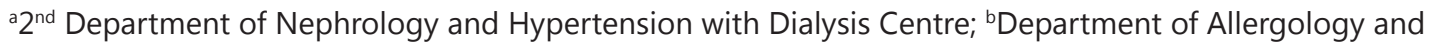 \\ Internal Medicine; ' $1^{\text {st }}$ Department of Nephrology and Transplantology, Medical University of Bialystok, \\ Bialystok, Poland
}

\section{Key Words}

Chronic kidney disease $\cdot$ Hepcidin $•$ Inflammation $•$ Iron

\begin{abstract}
Background/Aims: One of the most common causes of anemia of chronic disease (ACD) is chronic kidney disease. The main pathomechanism responsible for ACD is subclinical inflammation. The key element involved in iron metabolism is hepcidin, however, studies on new indices of iron status are in progress. The aim of the study was to assess the iron status in patients in early stages of chronic kidney disease, iron correlation with inflammation parameters and novel biomarkers of iron metabolism. Methods: The study included 69 patients. Standard laboratory measurements were used to measure the iron status, complete blood count, fibrinogen, prothrombin index, C-reactive protein concentration (CRP), creatinine, urea, uric acid. Commercially available kits were used to measure high-sensitivity CRP, interleukin 6 (IL-6), hepcidin-25, hemojuvelin, soluble transferrin receptor (sTfR), growth differentiation factor-15 (GDF-15) and zonulin. Results: Absolute iron deficiency was present in $17 \%$ of the patients, functional iron deficiency was present in $12 \%$ of the patients. Functional iron deficiency was associated with significantly higher serum levels of fibrinogen, ferritin, transferrin saturation, total iron binding capacity, hepcidin and older age relative to patients with absolute iron deficiency. In comparison with patients without iron deficiency, patients with functional iron deficiency were older, with lower prothrombin index, higher fibrinogen, CRP, hsCRP, sTfR, GDF-15, urea and lower eGFR. Hepcidin was predicted by markers of inflammation:ferritin, fibrinogen and IL-6. Conclusion: Inflammation is correlated with iron status. Novel biomarkers of iron metabolism might be useful to distinguish iron deficiency anemia connected with inflammation and absolute iron deficiency.
\end{abstract}




\section{Kidney Blood Pressure Research}

Kidney Blood Press Res 2015;40:366-373

\begin{tabular}{l|l}
\hline DOI: $10.1159 / 000368512$ & C 2015 S. Karger AG, Basel
\end{tabular}

Published online: June 20, 2015

www.karger.com/kbr

Łukaszyk/Łukaszyk/Koc-Żórawska/Tobolczyk/Bodzenta-Łukaszyk/Małyszko: Iron in Early CKD

\section{Introduction}

Iron is an essential element for the functioning of all living organisms. On one hand the positive association of iron overload and infection is well researched; for instance the excess of iron contributes to promote the development of tuberculosis and malaria [1,2]. Moreover, increased iron stores through its impact on inflammation and production of reactive oxygen species are related to type 1 and 2 diabetes [3], chronic liver diseases [4] and cancer [5]. On the other hand iron deficiency (ID) may lead to impaired production of hemoglobin and result in development of iron deficiency anemia, which is a widespread public health problem. However the mere iron deficiency may have a significant impact on health. It has been demonstrated that ID, regardless of anemia is associated with poor prognosis and increased mortality in patients with heart failure [6]. Iron deficiency is particularly common in patients with chronic diseases accompanied by inflammation, such as chronic kidney disease, heart failure, bowel inflammatory disease. Absolute iron deficiency is diagnosed when TSAT falls below 20 percent and the serum ferritin concentration is below $100 \mathrm{ng} / \mathrm{mL}$, while functional iron deficiency is defined as serum ferritin 100-300 $\mu \mathrm{g} / \mathrm{L}$ and TSAT $<20 \%$ [7]. The association between iron and inflammation remained unclear until the discovery of hepcidin-25 [8], a 25-aminoacid peptide, synthesized in hepatocytes. It is one of the key elements involved in iron metabolism. Hepcidin-25 secretion increases in response to iron overload, inflammation, infection and hypoxia [9]. It is also known as an acute-phase reactant [10]. Multiple proteins are involved in hepcidin-25 regulation and metabolism - hemojuvelin (HJV), human hemochromatosis protein (HFE), bone morphogenetic proteins (BMP), soluble transferrin receptors (sTfR), growth differentiation factor-15 (GDF-15), interleukin-6 (IL-6).

Previous studies on iron deficiency and kidney diseases concerned only the patients with end stage kidney disease or patients on renal replacement therapy. The aim of this study was to assess the iron status in patients in early stages of chronic kidney disease $\left(2^{\text {nd }}\right.$ and $3^{\text {rd }}$ stage), iron correlation with inflammation parameters and novel biomarkers of iron metabolism.

\section{Patients and Methods}

\section{Study population}

The studies were performed on 69 patients, including 26 patients with absolute iron deficiency and 7 patients with functional iron deficiency. Thirty six patients were in $2^{\text {nd }}$ and 6 patients were in $3^{\text {rd }}$ stage of chronic kidney disease, GFR (glomerular filtration rate) $60-89 \mathrm{ml} / \mathrm{min}$ and $30-59 \mathrm{ml} / \mathrm{min}$ respectively, calculated from CKD-EPI (Chronic Kidney Disease Epidemiology Collaboration) equation according to the latest KDIGO guidelines [11]. The inclusion criteria were as follows: age $\geq 18$ years; stable clinical state; no thrombosis or inflammation; absence of acute cardiovascular complication (including uncontrolled hypertension, acute coronary syndrome, acute heart failure). Exclusion criteria included: acute inflammation; active cancer; any anemia and/or iron deficiency treatment; blood transfusions within 3 months preceding the study, immunosuppressive therapy. We defined results based in iron deficiency parameters internationally accepted for CKD patients [7] i.e. absolute iron deficiency is defined as serum ferritin $<100 \mu \mathrm{g} / \mathrm{L}$ and TSAT $<20 \%$. Functional iron deficiency is defined as serum ferritin 100-300 $\mu \mathrm{g} / \mathrm{L}$ and TSAT $<20 \%$.

The study protocol was approved by the local Medical University Ethics Committee. All patients were fully informed about the study and gave their consent.

\section{Laboratory measurements}

All venous blood samples were taken in the morning after an overnight rest. Hematological measurements were made in fresh venous blood with EDTA and clotted blood. The plasma and serum were centrifuging and frozen at $-70^{\circ} \mathrm{C}$ until further laboratory analysis. Hemoglobin concentration $(\mathrm{Hb})$, red blood count (RBC), hematocrit (HCT), platelets count, fibrinogen, C-reactive protein concentration (CRP), 


\section{Kidney \\ Blood Pressure Research}

creatinine, urea, uric acid and prothrombin index were measured using standard laboratory methods (automated system) in a central laboratory.

The following iron metabolism biomarkers were measured directly: iron concentration, total iron binding capacity (TIBC), ferritin. Transferrin saturation (TSAT) was calculated as the ratio of serum iron and TIBC and expressed as a percentage.

Commercially available kits were used to measure: hepcidin-25 (EIA Kit, Peninsula Laboratories, LLC, Bachem Group, USA), HJV (USCN Life, Wuhan, China), sTfR (R\&D Systems, Minneapolis, USA), GDF-15 (R\&D Systems, Minneapolis, USA), IL-6 (R\&D Systems, Minneapolis, USA), hsCRP (CRP Elisa Kit- LDN Labor Diagnostika Nord GmbH\&Co KG, Nordhorn, Germany), zonulin (Immundiagnostik AG, Bensheim, Germany).

The CKD-EPI equation was used to estimate a glomerular filtration rate.

\section{Statistical analysis}

The data were analyzed using Statistica 10.0 computer software. If possible, data were logarithmically transformed to achieve normal distribution. Measurements normally distributed are reported as mean \pm $\mathrm{SD}$, and non-normally distributed as median \pm minimal-maximal value. Analysis of variance (ANOVA) (with post hoc Tukey test for unequal groups) or Kruskall-Wallis ANOVA (the difference between the mean of two variables was calculated by Mann-Whitney U test) were used in statistical analysis to compare differences between groups with $\mathrm{p}<0.05$ considered statistically significant, when appropriate. Analyses of the correlation of each parameter were performed using Pearson or Spearman correlation coefficients. $\mathrm{P}<0.05$ was considered significant.

\section{Results}

Clinical and biochemical parameters of the groups of patients are presented in the Table 1. Functional iron deficiency was associated with significantly higher serum levels of fibrinogen, ferritin, hepcidin, transferrin saturation and older age relative to patients with absolute iron deficiency. In comparison with patients without iron deficiency, patients with

Table 1. Clinical and biochemical characteristic of patients with absolute and functional iron deficiency

\begin{tabular}{|c|c|c|c|c|c|c|}
\hline & $\begin{array}{l}\begin{array}{l}\text { Absolute iron deficiency } \\
\text { (AID) } \\
n=12 \\
\end{array}\end{array}$ & $\begin{array}{l}\text { Functional iron deficiency } \\
\text { (FID) } \\
n=8\end{array}$ & $\begin{array}{l}\text { Normal iron level } \\
\mathrm{N}=49\end{array}$ & $\begin{array}{l}\text { P value } \\
\text { FID vs } \\
\text { normal }\end{array}$ & $\begin{array}{l}\text { P value } \\
\text { AID vs } \\
\text { normal }\end{array}$ & $\begin{array}{l}\text { P Value } \\
\text { FID vs } \\
\text { AID } \\
\end{array}$ \\
\hline age, years & $51.58 \pm 19.4$ & $72.5 \pm 13.0$ & $54.75 \pm 16.9$ & 0.007 & 0.57 & 0.016 \\
\hline $\mathrm{BMI}, \mathrm{kg} / \mathrm{m}^{2}$ & $26.33 \pm 5.3$ & $27.7 \pm 5.0$ & $27.19 \pm 5.72$ & 0.83 & 0.63 & 0.57 \\
\hline WBC, $\times 10^{6} / 1$ & $7.82 \pm 3.1$ & $7.0 \pm 2.2$ & $7.64 \pm 2.07$ & 0.45 & 0.81 & 0.54 \\
\hline $\mathrm{Hb}, \mathrm{g} / \mathrm{dl}$ & $12.36 \pm 2.3$ & $13.7 \pm 1.5$ & $14.4 \pm 1.68$ & 0.26 & 0.001 & 0.18 \\
\hline $\mathrm{RBC}, \mathrm{x} 10^{9} / 1$ & $4.86 \pm 0.5$ & $4.7 \pm 0.6$ & $4.86 \pm 0.58$ & 0.34 & 0.18 & 0.88 \\
\hline HCT, $\%$ & $43.24 \pm 6.6$ & $41.3 \pm 4.8$ & $43.24 \pm 5.17$ & 0.69 & 0.007 & 0.28 \\
\hline PLT, $x 10^{9} / 1$ & $279.08 \pm 56.95$ & $250.9 \pm 85.86$ & $262.1 \pm 107.62$ & 0.78 & 0.6 & 0.39 \\
\hline $\mathrm{PT}$ index (\%) & $82.29 \pm 34.2$ & $88.38 \pm 32.97$ & $108.0 \pm 18.67$ & 0.028 & 0.007 & 0.73 \\
\hline fibrinogen, mg/dl & $353.45 \pm 104.0$ & $494.9 \pm 137.4$ & $349.02 \pm 85.9$ & $<0.001$ & 0.88 & 0.024 \\
\hline iron, $\mu \mathrm{g} / \mathrm{dl}$ & 42.013 .1 & $45.5 \pm 13.9$ & $98.65 \pm 27.51$ & $<0.001$ & $<0.001$ & 0.57 \\
\hline TIBC, $\mathrm{ng} / \mathrm{ml}$ & $353.17 \pm 74.9$ & $272.0 \pm 55.0$ & $288.38 \pm 42.98$ & 0.34 & $<0.001$ & 0.01 \\
\hline TSAT, $\%$ & $12.34 \pm 4.4$ & $16.5 \pm 3.2$ & $34.69 \pm 11.17$ & $<0.001$ & $<0.001$ & 0.03 \\
\hline ferritin, ng/ml & $62.25(18.55-71.3)$ & $207.0(105.7-389.1)$ & $119.75(91.7-182.3)$ & 0.13 & $<0.001$ & $<0.001$ \\
\hline $\mathrm{CRP}, \mathrm{mg} / \mathrm{l}$ & $4.15(1.4-10.4)$ & $7.05 \pm(2.65-40.7)$ & $6.82(1.1-7.0)$ & 0.01 & 0.32 & 0.23 \\
\hline creatinine, $\mathrm{mg} / \mathrm{ml}$ & $0.85 \pm 0.2$ & $0.9 \pm 0.2$ & $0.85 \pm 0.14$ & 0.22 & 0.98 & 0.47 \\
\hline $\mathrm{eGFR}, \mathrm{ml} / \mathrm{min}$ & $88.51 \pm 21.8$ & $72.3 \pm 16.5$ & $85.06 \pm 15.42$ & 0.036 & 0.99 & 0.17 \\
\hline urea, mg/dl & $36.17 \pm 26.7$ & $43.1 \pm 7.6$ & $34.09 \pm 10.75$ & 0.03 & 0.67 & 0.48 \\
\hline GDF-15, pg/ml & $680.37(446.17-1640.5)$ & $1093.72(597.45-1501.6)$ & $640.22(434.55-804.59)$ & 0.03 & 0.41 & 0.37 \\
\hline $\mathrm{HJV}, \mu \mathrm{g} / \mathrm{ml}$ & $3.32(1.89-7.2)$ & $1.7(0.91-133.3)$ & $4.33(1.69-16.27)$ & 0.27 & 0.51 & 0.33 \\
\hline IL-6, pg/ml & $0.18(0.1-0.5)$ & $0.37(0.18-2.4)$ & $0.26(0.12-0.45)$ & 0.26 & 0.62 & 0.16 \\
\hline sTfR, nmol/l & $24.38(20.67-37.3)$ & $20.73(15.69-27.3)$ & $15.45(13.41-18.45)$ & 0.03 & $<0.001$ & 0.13 \\
\hline hepcidin, ng/ml & $2.09(0.73-8.9)$ & 38.08 (25.61-131.9) & $29.46(18.25-39.34)$ & 0.14 & $<0.001$ & $<0.001$ \\
\hline zonulin, $\mathrm{ng} / \mathrm{ml}$ & $34.85 \pm 5.6$ & $37.1 \pm 6.7$ & $34.42 \pm 8.25$ & 0.39 & 0.87 & 0.43 \\
\hline hsCRP, ng/ml & $6.49(1.92-12.7)$ & $6.97(3.5-32.82)$ & $2.4(1.3-8.6)$ & 0.02 & 0.28 & 0.42 \\
\hline
\end{tabular}

Data are presented as means \pm standard deviations or medians and interquartile ranges.

Abbreviations: BMI - body mass index, CRP - C-reactive protein, eGFR - estimated glomerular filtration rate, GDF-15 - growth differentiation factor, $\mathrm{Hb}$ - hemoglobin, HCT - hematocrit, hsCRP - high sensitivity C-reactive protein, IL-6 - interleukin-6, MCV - mean corpuscular volume, PLT - platelet count, PT - prothrombine time, RBC - red blood count, sTfR - soluble transferrin receptor, TIBC total iron binding capacity, TSAT - transferrin saturation, WBC - white blood count 


\section{Kidney \\ Blood Pressure Research}

\section{Kidney Blood Press Res 2015;40:366-373}

DOI: 10.1159/000368512

Published online: June 20, 2015

(c) 2015 S. Karger AG, Basel

www.karger.com/kbr

Łukaszyk/Łukaszyk/Koc-Żórawska/Tobolczyk/Bodzenta-Łukaszyk/Małyszko: Iron in Early CKD

Table 2. Correlations between parameters studied in patients with absolute iron deficiency

\begin{tabular}{|c|c|c|c|c|c|c|c|c|c|c|c|}
\hline & $\mathrm{HB}$ & Ferritin & $\begin{array}{l}\text { eGFR by } \\
\text { CKD-EPI }\end{array}$ & GDF-15 & IL-6 & sTfR & $\mathrm{HJV}$ & $\begin{array}{l}\text { hepci- } \\
\text { din-25 }\end{array}$ & zonulin & CRP & $\begin{array}{l}\text { fibrino- } \\
\text { gen }\end{array}$ \\
\hline HB & $\mathrm{x}$ & $0,60^{*}$ & $-0,13$ & $-0,05$ & $-0,90$ & $-0,17$ & 0,18 & 0,48 & $-0,16$ & 0,20 & 0,33 \\
\hline Ferritin & & $\mathrm{x}$ & $-0,14$ & 0,08 & 0,19 & $-0,36$ & 0,08 & $0,85^{*}$ & 0,01 & 0,41 & 0,60 \\
\hline eGFR by CKD-EPI & & & $\mathrm{x}$ & $-0,56$ & $-0,78^{*}$ & $-0,80^{*}$ & 0,20 & 0,00 & $-0,18$ & $-0,09$ & $-0,25$ \\
\hline GDF-15 & & & & $\mathrm{x}$ & 0,56 & $0,62^{*}$ & $-0,66^{*}$ & $-0,06$ & $-0,06$ & 0,29 & 0,001 \\
\hline IL-6 & & & & & $\mathrm{x}$ & $0,67^{*}$ & $-0,23$ & 0,19 & $-0,03$ & 0,05 & 0,16 \\
\hline sTfR & & & & & & $\mathrm{x}$ & $-0,20$ & $-0,34$ & 0,08 & 0,06 & 0,04 \\
\hline HJV & & & & & & & $\mathrm{x}$ & 0,41 & 0,22 & 0,18 & 0,32 \\
\hline hepcidin-25 & & & & & & & & $\mathrm{x}$ & 0,18 & 0,36 & 0,59 \\
\hline zonulin, & & & & & & & & & $\mathrm{x}$ & $-0,15$ & 0,15 \\
\hline CRP & & & & & & & & & & $\mathrm{x}$ & 0,57 \\
\hline fibrinogen & & & & & & & & & & & $\mathrm{x}$ \\
\hline$* \mathrm{p}<0.05$ & & & & & & & & & & & \\
\hline
\end{tabular}

Table 3. Correlations between parameters studied in patients with functional iron deficiency

\begin{tabular}{|c|c|c|c|c|c|c|c|c|c|c|c|}
\hline & $\mathrm{HB}$ & Ferritin & $\begin{array}{l}\text { eGFR by } \\
\text { CKD-EPI }\end{array}$ & GDF-15 & IL-6 & sTfR & HJV & $\begin{array}{l}\text { hepci- } \\
\text { din-25 }\end{array}$ & zonulin & CRP & $\begin{array}{c}\text { fibrino- } \\
\text { gen }\end{array}$ \\
\hline $\mathrm{HB}$ & $\mathrm{x}$ & 0,13 & 0,13 & $-0,68$ & $-0,56$ & $-0,49$ & 0,24 & $-0,36$ & 0,29 & $-0,48$ & $-0,67$ \\
\hline Ferritin & & $\mathrm{x}$ & $-0,10$ & 0,17 & 0,02 & 0,50 & 0,05 & 0,19 & 0,43 & 0,24 & 0,50 \\
\hline eGFR by CKD-EPI & & & $\mathrm{x}$ & $-0,69$ & 0,09 & $-0,33$ & $-0,38$ & 0,14 & 0,00 & 0,02 & 0,11 \\
\hline GDF-15 & & & & $\mathrm{x}$ & 0,55 & 0,52 & $-0,09$ & 0,07 & 0,02 & 0,45 & 0,61 \\
\hline IL-6 & & & & & $\mathrm{x}$ & 0,05 & $-0,52$ & 0,12 & 0,36 & 0,43 & 0,29 \\
\hline sTfR & & & & & & $\mathrm{x}$ & 0,45 & 0,69 & $-0,33$ & 0,59 & $0,79 *$ \\
\hline HJV & & & & & & & $\mathrm{x}$ & 0,50 & $-0,38$ & 0,05 & $-0,04$ \\
\hline hepcidin-25 & & & & & & & & $\mathrm{x}$ & $-0,21$ & 0,62 & 0,71 \\
\hline zonulin & & & & & & & & & $\mathrm{x}$ & $-0,24$ & $-0,42$ \\
\hline CRP & & & & & & & & & & $\mathrm{x}$ & $0,86^{*}$ \\
\hline fibrinogen & & & & & & & & & & & $\mathrm{x}$ \\
\hline${ }^{*} \mathrm{p}<0.05$ & & & & & & & & & & & \\
\hline
\end{tabular}

Table 4. Correlations between parameters studied in patients with normal iron levels

\begin{tabular}{|c|c|c|c|c|c|c|c|c|c|c|c|}
\hline & HB & $\begin{array}{c}\text { Ferrit } \\
\text { in } \\
\end{array}$ & $\begin{array}{l}\text { eGFR by } \\
\text { CKD-EPI }\end{array}$ & GDF-15 & IL-6 & sTfR & $\mathrm{HJV}$ & $\begin{array}{l}\text { hepci- } \\
\text { din-25 }\end{array}$ & zonulin & CRP & $\begin{array}{l}\text { fibrino- } \\
\text { gen }\end{array}$ \\
\hline HB & $\mathrm{x}$ & 0,05 & 0,11 & $-0,02$ & 0,01 & 0,21 & 0,14 & 0,15 & 0,11 & 0.06 & 0.07 \\
\hline Ferritin & & $\mathrm{x}$ & $-0,14$ & 0,07 & 0,04 & 0,18 & 0,02 & $0,55^{*}$ & $-0,11$ & 0,09 & 0,04 \\
\hline eGFR by CKD-EPI & & & $\mathrm{x}$ & $-0,44^{*}$ & $-0,17$ & 0,04 & $0,34^{*}$ & $-0,33^{*}$ & $-0,20$ & 0,17 & $-0,06$ \\
\hline GDF-15 & & & & $\mathrm{x}$ & 0,21 & 0,02 & $-0,38^{*}$ & 0,17 & $-0,05$ & $0,30^{*}$ & $0,36^{*}$ \\
\hline IL-6 & & & & & $\mathrm{x}$ & $-0,06$ & $-0,04$ & 0,60 & 0,21 & $0,45^{*}$ & 0,24 \\
\hline sTfR & & & & & & $\mathrm{x}$ & 0,15 & 0,03 & 0,04 & 0,19 & 0,28 \\
\hline HJV & & & & & & & $\mathrm{x}$ & $-0,16$ & $0,32 *$ & 0,01 & $-0,05$ \\
\hline hepcidin-25 & & & & & & & & $\mathrm{x}$ & 0,02 & $-0,01$ & 0,13 \\
\hline zonulin & & & & & & & & & $\mathrm{x}$ & 0,12 & 0,01 \\
\hline CRP & & & & & & & & & & $\mathrm{x}$ & $0,61^{*}$ \\
\hline fibrinogen & & & & & & & & & & & $\mathrm{x}$ \\
\hline${ }^{*} \mathrm{p}<0.05$ & & & & & & & & & & & \\
\hline
\end{tabular}

functional iron deficiency were older, with lower prothrombine index, higher fibrinogen, CRP, hsCRP, sTfR, GDF-15, urea and lower eGFR.

In patients with absolute iron deficiency correlations are given in the Table 2 and in patients with functional iron deficiency in the Table 3. In patients with normal iron levels several significant correlations were observed as presented in the Table 4. In all groups of patients GDF-15 was correlated eGFR $(r=-0.5, P<0.05)$ as well as with hsCRP $(r=0.4, P<$ $0.001)$, IL-6 $(r=0.38, P<0.05)$, sTfR $(r=0.26, P<0.05)$, HJV $(r=-0.33, P<0.05)$ and PT index $(r=-0.55, P<0.05)$ and strongly correlated with age $(r=0.68, P<0.05)$.

In patients with normal iron level, PT index was related in a univariate analysis to hepcidin $(r=0.37, P<0.05)$, and GDF-15 $(r=-0.37, P<0.05)$. In patients with iron deficiency, GDF-15 was strongly correlated in a univariate analysis with PT index $(r=-0.7, P<0.05)$. 


\section{Kidney Blood Pressure Research}

Kidney Blood Press Res 2015;40:366-373

\begin{tabular}{l|l}
\hline DOI: $10.1159 / 000368512$ & (c) 2015 S. Karger AG, Basel
\end{tabular}

Published online: June 20, 2015

www.karger.com/kbr

In multivariate analysis predictors of hepcidin-25 were IL-6 ( $\beta$-value was 0.269 ), fibrinogen ( $\beta$-value was 0.412 ) and ferritin ( $\beta$-value was 0.317 ) explaining $39 \%$ of the observed variations $(P=0.000988)$. SEM was 31.25.

\section{Discussion}

The association between inflammation and iron status prompted us to focus on the correlation of novel iron status parameters and an early stages of chronic kidney disease, which is a state of subclinical inflammation. Previous studies concerned the patients with end stage kidney disease or patients on renal replacement therapy. Malyszko et al. [12] revealed that the vast majority of hemodialysis patients presented functional iron deficiency that stemmed from subclinical inflammatory state. Therefore, in hemodialysis patients we should first pursuit to reveal and cure the reversible causes of inflammatory state.

Since the discovery of hepcidin-25 [8] it has become clear that iron status is connected with inflammation as well as with decreased clearance of hepcidin in chronic kidney disease. We have attempted to evaluate the impact of hepcidin-25 concentration on iron status, anemia and eGFR in patients in early stages of chronic kidney disease. In patients with functional iron deficiency strong relations between inflammation parameters and sTfR were confirmed. It is important to maintain the difference between absolute (ferritin $<100 \mathrm{ng} / \mathrm{mL}$ ) and functional iron deficiency (TSAT $<20 \%$; ferritin $>100 \mathrm{ng} / \mathrm{mL}$ ). In our study in patients with absolute iron deficiency we observed an association between hemoglobin and serum ferritin. The correlation between anemia, hepcidin and ferritin was particularly present in patients with lower eGFR [13]. In our study hepcidin was higher in patients with functional iron deficiency, when compared to patients with absolute iron deficiency. The correlation between hepcidin and ferritin was not find in patients with functional iron deficiency probably due to a limited sample size. The difference between functional iron deficiency and normal iron status did not reach, statistical significance, as it was reported previously in dialyzed patients [12], probably due to low number of patients with functional iron deficiency in the population studied with early stages of CKD.

Hemojuvelin plays an important role in juvenile hemochromatosis as a protein responsible for iron overload. It is also involved in hepcidin regulation [14]. It has been previously investigated that serum HJV is related to kidney function and iron metabolism in hemodialysis patients, but did not correlate with inflammation [15]. In our study we did not find any relation with studied parameters, except with zonulin in patients with normal iron status and with GDF-15 in absolute iron deficiency group.

GDF-15 is a member of transforming growth factor- $\beta$ cytokine superfamily and has been identified as the one of the iron status regulators. Oxidative stress and inflammation are known factors increasing GDF-15 expression [16]. What is more, in all study groups GDF15 was related to prothrombin index that may reflect an increased procoagulant activity during inflammation. The strong correlation between GDF-15 and age in association with shortened prothrombin index may reflect progression of atherosclerosis in the mechanism of endothelial activation and vascular inflammation [17].

Moreover GDF-15 was also significantly higher in patients with anemia according to the WHO definition (hemoglobin $<13 \mathrm{mg} / \mathrm{dl}$ for men and $<12 \mathrm{mg} / \mathrm{dl}$ for women) [18] compared to their nonanemic counterparts $(P=0.0025)$ similarly as in case of research on kidney allograft recipients [19], but in our study there was no association between GDF15 and hepcidin. It was previously investigated that higher circulating GDF-15 parallels deterioration in kidney function [20] that was also confirmed in our study.

Inflammation leads to IL-6 synthesis by macrophages, which acts on hepatocytes and induce hepcidin production [21]. In our study we did not confirm statistically significant difference between IL- 6 concentration in patients with and without iron deficiency. However, IL-6 level tended to increase as kidney function was impaired only in the group with absolute 


\section{Kidney Blood Pressure Research}

iron deficiency. In the recent paper by Shu et al. [22] IL-6 was increased in patients in tumorrelated anemia, but there was no correlation between IL-6 and hepcidin in patients with iron deficiency anemia. They suggest that iron deficiency may have more significant impact on reducing hepcidin levels than the inflammation itself. However, in healthy Japanese adults Nakagawa $\mathrm{H}$ et al. [23] showed that lower iron concentration was associated with increased serum IL-6. On the other hand Przybyszewska et al. [24] revealed a significantly higher concentration of IL-6 (in correlation with CRP) in patients with anemia of chronic disease in comparison to patients with iron deficiency anemia.

Soluble transferrin receptor is a dimer protein, which is a part of the transferrin receptor that has been enzymatically cleft and is present in serum [25]. It is a parameter that represents the amount of total transferrin receptor that is present in the body. The vast majority of sTfR is located in the red bone marrow. Measuring the concentration of sTfR is useful while assessing the gross mass of erythroid marrow and may be helpful while distinguishing between the anemia of chronic diseases and iron deficiency anemia [26].

In our study a univariate analysis confirmed that in the group of patients with functional iron deficiency sTfR was the only parameter that did not correlate with any of the inflammatory parameters. It only showed a strong correlation with renal function parameters in absolute iron deficiency. Although previous studies did not confirm unambiguous diagnostic utility of sTfR in complicated anemia [27], we suggest that sTfR could be a good clinical tool to reveal the underlying cause of anemia in early stages in CKD. Similarly to our results, studies have shown that the level of sTfR is markedly elevated in iron deficiency anemia but remains normal in anemia due to chronic inflammation without iron deficiency and thus may be of considerable help in differentiation between iron deficiency anemia and anemia of chronic disease-ACD [28-30]. However, further studies should be performed to explore other possible characteristics of this molecule.

Zonulin is a protein responsible for increasing intestinal permeability by affecting intracellular tight junctions. It has been previously reported that plasma zonulin level increases in some inflammatory states including sepsis, type 1 diabetes, celiac disease and obesity [31,32]. We hypothesized similar correlation in kidney disease or iron deficiency, but there was no relation with renal function. However, we observed a strong correlation with IL-6 and HJV. It may be useful to conduct similar research in patients with end stage kidney disease or patients on renal replacement therapy. In the recent paper by Malyszko et al [33] zonulin correlated with hematocrit, hemoglobin and erythrocyte count, but was not related to any iron parameters studied in kidney allograft recipients. Similarly, in heart transplant recipients zonulin correlated with hemoglobin, but was not related to iron status. In addition, kidney function, immunosuppressive regimen, NYHA class, gender, and presence of anemia did not affect zonulin level [34].

Some of the novel iron status parameters in univariate but not in multivariate analysis were associated with shortened prothrombin index. The following relation is probably associated with increased procoagulant activity in the state of inflammation. It might be also relevant to the possible associations between chronic kidney disease and liver disease [35]. We would like to stress that shortened prothombin index, which may be a novel finding, emphasize the importance of subclinical inflammation and associated increased risk of thrombotic tendency in this particular clinical setting. It has not been reported previously and requires further investigation.

There are several limitations of our study that deserve further clarification. The size of study group is small, that is why not all of the statistical analyses were possible. We also exclude other possible causes of anemia - deficiency of vitamin B12 or folic acid. We did not also assess erythropoietin levels and their relations to iron status as it was reported that hepcidin or prohepcidin were unaffected during therapy with erythropoiesis stimulating agents [36, 37]. It appears that some novel biomarkers i.e. HJV, zonulin do not add to the diagnosis of functional iron deficiency in early stages of CKD. Similarly, iron status or folate do not also differentiate between some complications of dialysis [38]. However, it seems 


\section{Kidney \\ Blood Pressure Research}

interesting that hepcidin and sTfR might help in distinguishing functional and absolute iron deficiency. The relation between kidney function and iron status is not obvious, therefore further studies are needed. In addition, this is a pilot study on iron status of chronic kidney disease, stressing the role of subclinical inflammation even in the early stages of CKD.

\section{Conclusion}

We confirmed that even subclinical inflammation is related to iron status. Novel biomarkers of iron metabolism might be useful to distinguish iron deficiency anemia connected with inflammation and absolute iron deficiency. From the clinical point of view any iron deficiency should guide a physician to rule out inflammation/infection as a priority.

\section{Disclosure Statement}

The authors of this manuscript state that they do not have any conflict of interests and nothing to disclose.

\section{References}

1 Murray MJ, Murray AB, Murray MB, Murray CJ: The adverse effect of iron repletion on the course of certain infections. Br Med J 1978;2:1113-1115.

2 Prentice AM: Iron metabolism, malaria and other infections: what is all the fuss about? J Nutr 2008;138:2537-2541.

3 Hansen JB, Moen IW, Mandrup-Poulsen T: Iron: the hard player in diabetes pathophysiology. Acta Physiol 2014;210:717-732.

4 Wallace DF, Subramaniam VN: Co-factors in liver disease: the role of HFE hereditary hemochromatosis and iron. Biochim Biophys Acta 2009;1790:663-667.

5 Toyokuni S: Role of iron in carcinogenesis: cancer as a ferrotoxic disease. Cancer Sci 2009;100:9-16.

6 Jankowska EA, Rozentryt P, Witkowska A, Nowak J, Hartmann O, Ponikowska B, Borodulin-Nadzieja L, Banasiak W, Polonski L, Filippatos G, McMurray JJ, Anker SD, Ponikowski P: Iron deficiency: an ominous sign in patients with systolic heart failure. Eur Heart J 2010;31:1872-1880.

7 Wish JB: Assessing iron status: Beyond serum ferritin and transferrin saturation. Clin J Am Soc Nephrol 2006;1:S4-S8.

8 Park C, Valore E, Waring A, Ganz T: Hepcidin, a urinary antimicrobial peptide synthesized in the liver. J Biol Chem 2001;276:7806-7810.

9 Nicolas G, Chauvet C, Viattel L, Danan JL, Bigard X, Devaux I, Beaumont C, Kahn A, Vaulont S: The gene encoding the iron regulatory peptide hepcidin is regulated by anemia, hypoxia, and inflammation. J Clin Invest 2002;110:1037-1044.

10 Nemeth E, Valore E, Territo M, Schiller G, Lichtenstein A, Ganz T: Hepcidin, a putative mediator of anemia of inflammation, is a type II acute phase protein. Blood 2003;101:2461-2463.

11 KDIGO 2012 Clinical Practice Guideline for the Evaluation and Management of Chronic Kidney Disease. Kidney Int Suppl 2013;3:1-150.

12 Malyszko J, Koc-Żórawska E, Levin-Iaina N, Małyszko J, Koźmiński P, Kobus G, Myśliwiec M: New parameters in iron metabolism and functional iron deficiency in patients on maintenance hemodialysis. Pol Arch Med Wewn 2012;122:537-542.

13 Mercadel L, Metzger M, Haymann JP, Thervet E, Boffa JJ, Flamant M, Vrtovsnik F, Houillier P, Froissart M, Stengel B; NephroTest Study Group: The Relation of Hepcidin to Iron Disorders, Inflammation and Hemoglobin in Chronic Kidney Disease. PLoS One 2014;30:e99781.

14 Lin L, Goldberg YP, Ganz T: Competitive regulation of hepcidin mRNA by soluble and cell-associated hemojuvelin. Blood 2005;106:2884-2889.

15 Malyszko J, Malyszko JS, Levin-Iaina N, Koc-Zorawska E, Kozminski P, Mysliwiec M: Is hemojuvelin a possible new player in iron metabolism in hemodialysis patients? Int Urol Nephrol 2012;44:1805-1811. 


\section{Kidney \\ Blood Pressure Research}

16 Breit SN, Johnen H, Cook AD, Tsai VW, Mohammad MG, Kuffner T, Zhang HP, Marquis CP, Jiang L, Lockwood G, Lee-Ng M, Husaini Y, Wu L, Hamilton JA, Brown DA: The TGF-beta superfamily cytokine, MIC-1/GDF15: a pleotrophic cytokine with roles in inflammation, cancer and metabolism. Growth Factors 2011;29:187-195.

17 Eggers KM, Kempf T, Lind L, Sundström J, Wallentin L, Wollert KC, Siegbahn A: Relations of growthdifferentiation factor-15 to biomarkers reflecting vascular pathologies in a population-based sample of elderly subjects. Scand J Clin Lab Invest 2012;72:45-51.

18 World Health Organization: Nutritional anemias: Report of a WHO Scientific Group. World Health Organ Tech Rep Ser 1968;405:5-37.

19 Malyszko J, Koc-Zorawska E, Malyszko JS, Glowinska I, Mysliwiec M, Macdougall IC: GDF15 is related to anemia and hepcidin in kidney allograft recipients. Nephron Clin Pract 2013;123:112-117.

20 Ho JE, Hwang SJ, Wollert KC, Larson MG, Cheng S, Kempf T, Vasan RS, Januzzi JL, Wang TJ, Fox CS: Biomarkers of cardiovascular stress and incident chronic kidney disease. Clin Chem 2013;59:1613-1620.

21 Andrews NC: Anemia of inflammation: the cytokine-hepcidin link. J Clin Invest 2004;113:1251-1253.

22 Shu T, Jing C, Lv Z, Xie Y, Xu J, Wu J: Hepcidin in tumor-related iron deficiency anemia and tumor-related anemia of chronic disease: pathogenic mechanisms and diagnosis. Eur J Haematol 2015;94:67-73.

23 Nakagawa H, Tamura T, Mitsuda Y, Goto Y, Kamiya Y, Kondo T, Wakai K, Hamajima N: Inverse correlation between serum interleukin- 6 and iron levels among Japanese adults: a cross-sectional study. BMC Hematol 2014;14:6.

24 Przybyszewska J, Żekanowska E, Kędziora-Kornatowska K, Boinska J, Cichon R, Porzych K: Serum prohepcidin and other iron metabolism parameters in elderly patients with anemia of chronic disease and with iron deficiency anemia. Pol Arch Med Wewn 2013;123:105-111.

25 Cook JD, Skikne BS, Baynes RD: Serum Transferrin Receptor. Annu Rev Med 1993;44:63-74.

26 Ferguson BJ, Skikne BS, Simpson KM, Baynes RD, Cook JD: Serum transferrin receptor distinguishes the anemia of chronic disease from iron deficiency anemia. J Lab Clin Med 1992;119:385-390.

27 Braga F, Infusino I, Dolci A, Panteghini M: Soluble transferrin receptor in complicated anemia. Clin Chim Acta 2014;431:143-147.

28 Ferguson BJ, Skikne BS, Simpson KM, Baynes RD, Cook JD: Serum transferrin receptor distinguishes the anemia of chronic disease from IDA. J Lab Clin Med 1992;119:385-390.

29 Cazzola M, Ponchio L, de Benedeti F, Ravelli A, Rosti V, Beguin Y, Invernizzi R, Barosi G, Martini A: Defective iron supply for erythropoiesis and adequate endogenous erythropoietin production in the anemia associated with systemic-onset juvenile chronic arthritis. Blood 1996;87:4824-4830.

30 Berlin T, Meyer A, Rotman-Pikielny P, Natur A, Levy Y: Soluble Transferrin Receptor as a Diagnostic Laboratory Test for Detection of Iron Deficiency Anemia in Hospitalized Patients with Acute Illness. IMAJ 2011:13:96-98.

31 Fasano A: Zonulin and Its Regulation of Intestinal Barrier Function: The Biological Door to Inflammation, Autoimmunity, and Cancer. Physiol Rev 2011;91:151-175.

32 Klaus DA, Motal MC, Burger-Klepp U, Marschalek C, Schmidt EM, Lebherz-Eichinger D, Krenn CG, Roth GA: Increased plasma zonulin in patients with sepsis. Biochem Med 2013;23:107-111.

33 Malyszko J, Koc-Zorawska E, Levin-Iaina N, Malyszko J: Zonulin, iron status and anemia in kidney transplant recipients; are they related? Transplant Proc 2014;46:2644-2646.

34 Przybylowski P, Nowak E, Janik L, Wasilewski G, Malyszko J: Zonulin and iron metabolism in heart transplant recipients. Transplant Proc 2014;46:2856-2859.

35 Mikolasevic I, Racki S, Bubic I, Jelic I, Stimac D, Orlic L: Chronic kidney disease and nonalcoholic Fatty liver disease proven by transient elastography. Kidney Blood Press Res 2013;37:305-310.

36 Morikami Y, Fujimori A, Okada S, Kumei M, Mizobuchi N, Sakai M: Twice-monthly administration of a lower dose of epoetin Beta pegol can maintain adequate hemoglobin levels in hemodialysis patients. Ther Apher Dial 2015;19:138-143.

37 Choi JY, Yang CW, Kim YH, Joo KW, Yoo TH, Lee KW, Lee SH, Moon JY, Shin SK,Huh W, Kim NH, Park SH, Kim CD, Kim YL: Effect of conversion from ESA with shorter half-life to CERA once monthly for maintaining $\mathrm{Hb}$ concentration in pre-dialysis CKD patients. Kidney Blood Press Res 2013;37:259-268.

38 Gade K, Blaschke S, Rodenbeck A, Becker A, Anderson-Schmidt H, Cohrs S: Uremic restless legs syndrome (RLS) and sleep quality in patients with end-stage renal disease on hemodialysis: potential role of homocysteine and parathyroid hormone. Kidney Blood Press Res 2013;37:458-463. 